\title{
The Public Business Support Services: Does It Really Works?
}

\author{
Mohd Nor Hakimin Yusoff $^{1} \&$ Fakhrul Anwar Zainol $^{2}$ \\ ${ }^{1}$ Faculty of Entrepreneurship and Business, Universiti Malaysia Kelantan, Malaysia \\ ${ }^{2}$ Centre of Entrepreneurship, Universiti Sultan Zainal Abidin, Terengganu, Malaysia \\ Correspondence: Mohd Nor Hakimin Yusoff, Faculty of Entrepreneurship and Business, Universiti Malaysia \\ Kelantan, Malaysia. Tel: 60-9-771-7000. E-mail: hakimin@umk.edu.my
}

Received: March 11, 2014 Accepted: May 8, 2014 Online Published: June 24, 2014

doi:10.5539/ass.v10n14p106 URL: http://dx.doi.org/10.5539/ass.v10n14p106

\begin{abstract}
The establishment of business entity, especially among Malays ethnic, experienced a rapid development since Malaysia has gained independence from British colonial in 1957. In 1970 the government has launched a New Economic Policy (1970-1990) which aimed to increase Malays ownership in economic activities without sidelining other races. However, at the end of the period, the targeted figure of $30 \%$ Bumiputera (indigenous) ownership is far from achieved. The government was alerted and has conducted a substantial program to overcome the problems. Thus, this study aimed to investigate the factors that hinder SMEs from using the services, hoping that the awareness is no more a key issue. This study is also to assess non-users perception of firms' performance in the absence of the government support services. The study used cross sectional data from database of national SME supervisory body. The respondents are Malays SMEs all over Malaysia.
\end{abstract}

Keywords: Malay, public business support services, SME and firm performance

\section{Introduction}

The establishment of business entity, especially among Malays experience rapid development since Malaysia has gained independence from British colonial in 1957. The government focuses on Malay entrepreneurs as one of the tools to stabilize the distribution of wealth among ethnic. The greatest impact on inequitable distribution of wealth witnessed a tragic incident in 1969 where the country has to pay a very high price when ethnic riot occurs. As a turning point, the government had come out with 20 years economic plan (1970-1990) which was called The New Economic Policy (NEP). It's objective was to eradicate poverty and redistribution of wealth among ethnics (Malaysia, 1971). So, to achieve the objective the government had encouraged Malays to venture into entrepreneurship activities. The government recognized and believed that entrepreneurship is one of the effective tools to achieve the objectives outlined in the New Economic Policy.

With the mission to sustain prosperity via fair economic distribution the government encouraged Malays to involve in the entrepreneurship activities. During NEP period a number of agencies were established to provide business support for the Malays. It is important to note that, the NEP has targeted by the end of NEP period 30\% of national wealth goes to Malay (Malaysia, 1971). Since the beginning of NEP, the government had spent billions of Ringgit in providing supports for Malays and natives people covering various services. The supports begin from the business startup, up until business expansion and internationalization. However, at the end of the period, the targeted figure is far achieved. It is believed that the unsatisfactory achievement has to do with the role of business support services. Previous study shows that a significant number of Malays SMEs do not utilized the services. So, this study aimed to investigate the factors that hinder SMEs from using the services and to assess SMEs' perception on their performance in the absence of the government business support services.

\section{Literature Review}

This section presents the concept of the effectiveness of business support services by discussing how it was measured. Further discussion is based on the findings from previous studies on the impact of the external business support services on SMEs firms' performance.

\subsection{The Effectiveness of the Business Support Services}

In the study of business support, the effectiveness of the services is measured at two different stages. First, the measurement is made on the frequency of usage of the services as the Resource-based Theory suggested that 
more frequent usage has positive impact on the firms' performance. Second, the effectiveness is measured based on the direct impact on firms' performance.

\subsection{Frequency of Usage}

The measurement is based on the how frequent SMEs seek for advice from the agency. In the study conducted by Berry, Sweeting and Goto (2006) in UK, the study used scale from always being used to never being use in measuring the effectiveness of the services provided by a range of services suppliers. In other study, Boter and Lundstrom (2006), exploited scale of used regularly to never being used to measure the usage of the services. The services are considers effective and 'working' when the utilisation rate is satisfactory. Generally, the studies on the government backed-up business support found that the services are not popular among SMEs (Dyer \& Ross, 2008; Hakimin, 2010; Lewis, Massey, Ashby, Coetzer, \& Harris, 2007). In turn, the services experience low utilisation rate and perceived as giving less impact on firms' performance.

\subsection{Impact on Firms' Performance}

Secondly, the effectiveness of the services is measured on the direct impact of the usage of the services to the firms' performance. Robson and Bennet (2000) use growth to measure the impact of the external business support. On the other hand, Wren and Storey (2002) applied sales and number of employees in addition to firms' growth in measuring the firms' performance.

\subsection{The Impact of the External Business Support}

The studies of the impact of the external intervention which refers to business support services to SMEs firms' performance have come out with mixed result. Berry, Sweeting and Goto (2006) in their study found that the support services have positive impact on firms' performance. The study was supported by Wiklund and Shepherd (2005) who argued that regular contact with support agencies give favorable impact on firms' growth. In another study by Boter and Lundstrom (2006) shares the same view. However, Curran and Blackburn (2000) had questioned the government's involvement in SMEs' activities and claimed that the government's intervention only act as a political tool to gain political support and then they leave the programs later as white elephants. This is constant with the study by Westhead and Birley (1995) who posit that the government's backed-up support services did not give significant impact on firms' performance. This finding was further confirmed by Robson and Bennet (2000) who concluded that the effect of the services is doubted.

Previous study on the government sponsored business support conducted in other regions found that, the services are not popular among SMEs for a number of reasons (Berry et al., 2006; Josee \& Etienne, 2007). Among others are bureaucracy and incompetency of the advisors. Most of the SMEs are more willing to utilise the services provided by private agencies which are faster, in line with their needs and it comes along with competent staff (Ian. Chaston \& Sue, 1998).

\subsection{Local Scenario}

Theoretically, the government support services are provided especially to assist Malays whose entrepreneur activities are far behind other ethnics. As this group of ethnic is a novice entrepreneur, without government intervention it is quite difficult for them to compete with other players and survive. A newly set up business entity is known to have difficulties to acquire facilities and support from private institutions which is operated on profit-making basis (Brown, Earle, \& Lup, 2005). With a wide range of services provided, supposedly the Malays SMEs should utilise it and enjoy the benefit. Surprisingly, studies show that the services are under utilised. According to Abdul Aziz and Faoziah (2009), to obtain financial support SMEs prefer to deal with commercial bank over the government agencies.

Khairudin et al., (2009) in their study found that, only $10.1 \%$ of the respondents are aware of the services provided by one of the credit guarantee in Malaysia. It is also found that most of the SMEs are unaware of the existence of the credit guarantee services sponsored by the government in their locality. This finding further supported by a study conducted by Oz and Tiesdell cited in Emslie and Bent (2007); Pilgrim and Meier (1994) cited in Khairudin et al. (2007), Foziah et al. (2006), which stated that lack of awareness of the existence of business assistance services provided by the government agencies is among the reasons for the poor take up rate. As the consequences, the government sponsored programs are not fully utilised by SMEs and obtain a poor take up rate (Boter \& Lundstrom, 2005; Berry \& Sweating, 2006; Ramsden \& Bennet, 2005; Matton, 1999; cited in Devin et al., 2005). It is recognised that lack of awareness is one of the factors of poor utilisation of government sponsored business assistance. 


\section{Methodology}

This study used closed ended questionnaire survey to get information about the usage of the government business support services among Malays SMEs and the factors that lies behind the usage or non-usage of the services offered. The questionnaire was developed based on previous literatures. 3,832 sets of questionnaires were distributed via mail to all the owners of Malays SMEs in Malaysia in July 2012 together with a stamped return envelope.

The questionnaire was divided into 4 sections. Section I asking respondents either they use or do not use the government business support services. Section II comprises of 12 statements about the reasons for not using the services. The respondents need to mark any chosen reason and they can mark more than one reason. Section III is the measurement for respondent's firms' performance. There were 5 items using 5 point Likert Scale which 1 represent strongly disagree and 5 refers to strongly agree. Respondents are required to give their assessment on the statement based on comparison with competitors' firm. For instance, statement in item 1: Compares to our competitors, our business has better market position. Finally, Section IV comprises of questions on demographic information, which respondents need to mark the choices given.

By late October 2012, 728 questionnaires were returned and have gone through preliminary data analysis. Out of 728 questionnaires returned, 58 questionnaires were dropped due to (1) 21 set of the questionnaire were not completed more than $10 \%$ and (2) 37 set of questionnaires were not answered by owner of the firms. The requirement for the owner to attempt to answer the questionnaires is to get the response from the person heading the top management. The total number response rate is $17.48 \%$. This response rate is in line with other studies conducted locally with the ability to obtain responses between 15\%-25\%. From 670 set of questionnaires returned, $333(49.7 \%)$ respondents do not utilise the government business support services. The data then was analysed using SPSS 19.0 to get the result. The survey questionnaires were adapted from previous literatures.

\section{Results}

The respondents are equally distributed among 14 states with the highest respondents from Terengganu followed by Selangor. The lowest responds is from Perlis, which is the smallest state in Malaysia. Perlis also has the least number of Malays SMEs in the country. The population size may justify the low responses from Perlis.

Table 1. List of respondents

\begin{tabular}{lll}
\hline State & $\mathrm{N}$ & $\%$ \\
\hline Kedah & 32 & 9.6 \\
Kelantan & 28 & 8.4 \\
Perlis & 5 & 1.5 \\
Penang & 21 & 6.3 \\
Perak & 20 & 6.0 \\
Federal Territory & 29 & 8.7 \\
Sabah & 15 & 4.5 \\
Sarawak & 28 & 8.4 \\
Pahang & 9 & 2.7 \\
Selangor & 39 & 11.7 \\
Melaka & 20 & 6.0 \\
N. Sembilan & 11 & 3.3 \\
Johor & 30 & 9.0 \\
Terengganu & 46 & 13.8 \\
Total & 333 & 100.0 \\
\hline
\end{tabular}

Table 2. Respondents/owners profile

\begin{tabular}{llll}
\hline Age & $\mathrm{N}$ & $\%$ \\
\hline$<25$ & 22 & 6.6 \\
$26-35$ & 83 & 24.9 \\
$36-45$ & 92 & 27.6 \\
$46-55$ & 104 & 31.2 \\
$56-65$ & 29 & 8.7 \\
$>65$ & 3 & 0.9 \\
\hline
\end{tabular}




\begin{tabular}{lll}
\hline Age & $\mathrm{N}$ & $\%$ \\
\hline Gender & & 68.5 \\
Male & 228 & 31.5 \\
Female & 105 & 9.6 \\
Level of Education & & 32.4 \\
Lower Certificate of Education & 32 & 9.9 \\
Malaysia Certificate of Education & 108 & 28.5 \\
Certificate & 33 & 14.1 \\
Diploma & 95 & 3.9 \\
First Degree & 47 & 1.5 \\
Master Degree & 13 & 85.6 \\
Phd & 5 & 13.2 \\
Designation & & 1.2 \\
Owner & 285 & \\
CEO & 44 & \\
General Manager & 4 & \\
\hline
\end{tabular}

Table 3. Firms profile

\begin{tabular}{|c|c|c|}
\hline & $\mathrm{N}$ & $\%$ \\
\hline \multicolumn{3}{|c|}{ Number of employees } \\
\hline $1-5 y$ & 207 & 62.2 \\
\hline $6-20 y$ & 91 & 27.3 \\
\hline $21-35 y$ & 23 & 6.9 \\
\hline $36-50 y$ & 7 & 2.1 \\
\hline$>50 y$ & 5 & 1.5 \\
\hline \multicolumn{3}{|l|}{ Age of firms } \\
\hline$<1$ & 28 & 8.4 \\
\hline $1-5 y$ & 105 & 31.5 \\
\hline $6-10 y$ & 87 & 26.1 \\
\hline $11-15 y$ & 53 & 15.9 \\
\hline $16-20 y$ & 24 & 7.2 \\
\hline$>20 y$ & 36 & 10.8 \\
\hline \multicolumn{3}{|l|}{ State } \\
\hline Kedah & 32 & 9.6 \\
\hline Kelantan & 28 & 8.4 \\
\hline Perlis & 5 & 1.5 \\
\hline Penang & 21 & 6.3 \\
\hline Perak & 20 & 6.0 \\
\hline Fed Territory & 29 & 8.7 \\
\hline Sabah & 15 & 4.5 \\
\hline Sarawak & 28 & 8.4 \\
\hline Pahang & 9 & 2.7 \\
\hline Selangor & 39 & 11.7 \\
\hline Melaka & 20 & 6.0 \\
\hline N. Sembilan & 11 & 3.3 \\
\hline Johor & 30 & 9.0 \\
\hline Terengganu & 46 & 13.8 \\
\hline \multicolumn{3}{|l|}{ Location } \\
\hline Urban & 226 & 67.9 \\
\hline Rural & 107 & 32.1 \\
\hline \multicolumn{3}{|l|}{ Sector } \\
\hline Manufacturing & 50 & 15.0 \\
\hline Service & 216 & 64.9 \\
\hline Agriculture & 16 & 4.8 \\
\hline Construction & 51 & 15.3 \\
\hline
\end{tabular}


The majority of the respondents are male $(68.5 \%)$ and $60 \%$ of them are under 45 years old. About $60 \%$ respondents possess higher education with $28.5 \%$ obtained diploma, $14.1 \%$ first degree, $3.9 \%$ master degree and $1.5 \%$ Phd.

Out of 333 respondents, the majority (64.9\%) are involved in service activities. Manufacturing represent $15 \%$ of respondents and the balance are SMEs which running agriculture based activities $(4.8 \%)$ and construction $(15.3 \%)$. In terms of size, $62 \%$ respondents are categorised as micro-scale firms with 5 and less of full time employees and $37 \%$ categorised as small-scale firms with a number of employees between 5 to 50 . The balance of $1.5 \%$ is medium size firms with a number of employees more than 50 . The majority of respondents run the business in urban areas and $60 \%$ of the respondents have been more than 5 years in business.

Of the 333 respondents, $73.57 \%$ agreed that long process and complicated procedure obtain the services is the most popular reason SMEs are not utilising the GBSS. The second is they did not know how to apply. This is related to first one and it is believed due to the long and complicated procedures. The third reason is insufficient resources where the fund is insufficient and respondents need to wait for new allocation from the government. Based on researchers' experience with one of the participants in a particular training session, the participant claimed that the fund is exhausted when he submit his application. From this study also, surprisingly $22.82 \%$ respondents are unaware about the services provided by the government. This factor becomes the fourth reason for not utilising the services.

Table 4. List of factor for not using the services

\begin{tabular}{lll}
\hline Reason & Frequency & $\%^{*}$ \\
\hline Insufficient resources & 83 & 24.92 \\
Not aware of the services & 76 & 22.82 \\
Services only for nascent business & 46 & 13.81 \\
Did not know about the services & 53 & 15.92 \\
Did not confident with the service offered & 46 & 13.81 \\
Poor fit between the business need and services available & 52 & 15.62 \\
Did not know to apply for the services & 115 & 34.53 \\
Concern about possibility of information leakage & 37 & 11.11 \\
Procedures are complicated & 245 & 73.57 \\
Did not understand about the product & 51 & 15.32 \\
Services quality is poor & 42 & 12.61 \\
High charges imposed for the services & 54 & 16.22 \\
Others & 20 & 6.01 \\
\hline
\end{tabular}

${ }^{*}$ Percentage out of total respondents of 333

To assess the firm's performance, respondents were asked to rate five items used in performance constructs. The measurement uses 5 point Likert-scale which scale of strongly disagree (1) to strongly agree (5). Respondents are required to give an assessment based on the comparison between respondents' firms and competitors' firms. The results show that $44.4 \%$ respondents agree that their firms have a better market position compared with competitors. Only $6.6 \%$ strongly agree that they have a better market position. In terms of market share, $39.0 \%$ agree that their market share is larger than competitors whereas $11 \%$ disagree with this statement. Respondents also agree that their firms experienced higher sales and employment growth, which response of $42 \%$ and $35.1 \%$ respectively. Finally, in terms of financial position, $48.3 \%$ of respondents agree that they recorded better financial position compare to competitors. Overall, the mean for items in performance construct are between 3.38 to 3.56 . It can be concluded that respondents do agree that their firms' performances are fairly better than competitors.

Table 5. Non-users' perception on firms' performance

\begin{tabular}{|c|c|c|c|c|c|c|c|c|c|c|}
\hline & \multicolumn{2}{|c|}{ Better market position } & \multicolumn{2}{|c|}{ Larger market share } & \multicolumn{2}{|c|}{ Higher sales growth } & \multicolumn{2}{|c|}{ Higher employment growth } & \multicolumn{2}{|c|}{ Better financial result } \\
\hline & $\mathrm{N}$ & $\%$ & $\mathrm{~N}$ & $\%$ & $\mathrm{~N}$ & $\%$ & $\mathrm{~N}$ & $\%$ & $\mathrm{~N}$ & $\%$ \\
\hline $\begin{array}{l}\text { Strongly } \\
\text { Disagree }\end{array}$ & 6 & 1.8 & 4 & 1.2 & 5 & 1.5 & 3 & .9 & 4 & 1.2 \\
\hline Disagree & 18 & 5.4 & 33 & 9.9 & 16 & 4.8 & 36 & 10.8 & 15 & 4.5 \\
\hline
\end{tabular}




\begin{tabular}{|c|c|c|c|c|c|c|c|c|c|c|}
\hline \multirow[b]{2}{*}{ Neutral } & \multicolumn{2}{|c|}{ Better market position } & \multicolumn{2}{|c|}{ Larger market share } & \multicolumn{2}{|c|}{ Higher sales growth } & \multicolumn{2}{|c|}{ Higher employment growth } & \multicolumn{2}{|c|}{ Better financial result } \\
\hline & 139 & 41.7 & 139 & 41.7 & 146 & 43.8 & 152 & 45.6 & 129 & 38.7 \\
\hline Agree & 148 & 44.4 & 130 & 39.0 & 140 & 42.0 & 117 & 35.1 & 161 & 48.3 \\
\hline $\begin{array}{l}\text { Strongly } \\
\text { Agree }\end{array}$ & 22 & 6.6 & 27 & 8.1 & 26 & 7.8 & 25 & 7.5 & 24 & 7.2 \\
\hline Total & 333 & 100.0 & 333 & 100.0 & 333 & 100.0 & 333 & 100.0 & 333 & 100.0 \\
\hline Mean & 3.49 & & 3.43 & & 3.50 & & 3.38 & & 3.56 & \\
\hline SD & .77 & & .82 & & .77 & & .81 & & .74 & \\
\hline
\end{tabular}

\section{Discussion}

The study found that about $49.7 \%$ of the respondents did not utilise the services provided by the government. The majority of the respondents failed to benefit from various programs due to the complicated procedures imposed by the agencies in obtaining the services. Another reason is that they do not know about the services and did not aware that there are available support programs from the government. This factor is quite alarming where $22 \%$ claimed they did not use it because they are unaware about the services. Therefore, a lot more should be done as the result of this study indicates that the message did not reach certain group of SMEs and the number is quite high $(22 \%)$. The result suggests that the awareness programs did not work well to certain groups of Malays SMEs, although the government has spent tons of money for awareness campaign and programs which covers roadshows, advertisements, exhibitions and expositions.

The issue of complicated procedure remains as the dominant factor for the failure to use the services. Salleh and Ndubisi (2006) reported that bureaucracy is one of the challenges that face the agencies to disseminate efficient services to SMEs. This is a long and overdue issue that remains unresolved. There are a lot of debates concerning bureaucracies, some authors argue that the long and complicated process in obtaining services from the government is related to the accountability and good governance in the public sector. The government is responsible and answerable to the public in particular on the money spent and activities held. In turn, the agencies must carefully act by keeping a comprehensive and detail record. This practice lead to lengthy process and a lot of forms need to be filled up. Bureaucracy leads to a rigid procedures and takes longer time to complete. This becomes problems to SMEs as long waiting time affected their daily operations.

There are also debates that complicated procedure is more on obtaining financial aid. The government sponsored programs are managed by government-link corporations which run as a profit oriented organisation. As a corporate body which focuses on profit making activities, giving out loan to SMEs is a risky activity in particular to micro and small sized SMEs. In order to mitigate the risk, the corporation involved needs a lot of information which sometimes is not readily available from applicants (SMEs). SMEs need to work out with other parties in order to produce the information. For instance, it is a normal practice by the financial institutions to ask for 3 years audited financial statements for corporations or endorsement by Public Accountant in the case of incorporated business entity. Obviously, most of the micro and small sized SMEs are incapable to employ qualified employee as accountant because the pay is high and it did not commensurate with their earnings. By imposing such conditions they need to engage with private party. Then the issue now is that by engaging private party, SMEs still needs to spend quite certain amount of money. Furthermore, it takes some time to prepare the documents. At the same time, the lodgment of the documents after spending much money and time did not give any guarantee for loan approval. This is the dilemma faced by the SMEs. They are in dire need for the services which should come with no cost upon application, but it turned to be a very expensive. Consequently, these factors become a distraction factor for SMEs in using the support services provided by the government.

Non-users SMEs assess their performance at a better position compares to their competitors. Thus, the findings reflect that the business support services offered by the government available in the market are not attractive to this group. Furthermore, this group of Malays SMEs believed their operations do not need intervention from the government.

\section{Conclusions}

Non-users of the government business support services were satisfied with their firm's performance and believed in the absence of the support services, the firm performs better than competitors. The majority of the respondents did not use the services on the reason of failure to comply with lengthy procedure and bureaucracy. Surprisingly, the awareness issues still exist besides various programs conducted to overcome the problems. There are a number of factors that can be overcome if the service providers really understand the nature of SMEs and their requirements. The problems of bureaucracy, complicated procedure and awareness, are long overdue and need 
serious attention from the government.

Non-users' rate is considered high when about half of the total Malays SMEs' population have not benefited from the programs. It is suggested that the government agencies review the terms and conditions stipulated in the services in order to cutoff those lengthy procedures. For financial support, the government backed-up financial institution for SMEs is suggested to review the whole procedure by considering not applying normal credit practices, in particular when assessing the loan application for micro and small sized SMEs. Imposing normal credit practices on nascent micro and small sized SMEs will discourage them as they are not capable to comply. For instance, recently, there was a new financial support services scheme dedicated to youth under 30 years old launched. It was announced that the support will come in the form of soft loan where the extension of financial aid to SMEs without third party guarantee. The fund is managed by one the development institution. However, in practices the facilities offered without guarantee, but SMEs need to put cash collateral which is equivalent to $10 \%$ of the loan amount. It is foreseen that the cash collateral imposed create difficulties for nascent Malay entrepreneur and again discourage them from using the facilities. Consequently, it spoilt the government objective of the new financial support scheme.

\section{References}

Abdul Aziz, L., \& Faoziah, I. (Eds.). (2009). Entrepreneurs' awareness of bank borrowing offered by government agencies and commercial bank. Kelantan: Universiti Malaysia Kelantan.

Berry, J. A., Sweeting, R., \& Goto, J. (2006). The effect of business advice on the performance of SMEs. Journal of Small Business and Enterprise Development, 13(1), 33-47. http://dx.doi.org/10.1108/146260 00610645298

Boter, H., \& Lundstrom, A. (2006). SME Perspectives on Business Support Services. Journal of Small Business and Enterprise Development, 12(2), 244-258. http://dx.doi.org/10.1108/14626000510594638

Brown, J. D., Earle, J. S., \& Lup, D. (2005). What Makes Small Firms Grow? Finance, Human Capital, Technical Assistance, and the Business Environment in Romania. Economic Development and Cultural Change, 54(1), 33-70. http://dx.doi.org/10.1086/431264

Curran, S. J., \& Blackburn, A. R. (2000). Panacea or White Elephant? A Critical Examination of the Proposed New Small Business Service and Response to the DTI Consultancy Paper. Regional Studies, 32(2), 181-206.

Dyer, M. L., \& Ross, A. C. (2008). Seeking Advice in a Dynamic and Complex Business Environment: Impact on the Success of Small Firms. Journal of Development Entrepreneurship, 13(2), 133-149. http://dx.doi. org/10.1142/S1084946708000892

Hakimin, Y. (Ed.). (2010). The utilisation of the government business support services: The senior adviser perspectives (Vol. 1). Kelantan: Universiti Malaysia Kelantan.

Ian. Chaston, \& Sue, B. (1998). Relationship Influencers: Determination of Affect in the Provision of Advisory Services to SME Sector Firms. Journal of European Industrial Training, 22(6), 249-256. http://dx.doi.org/ $10.1108 / 03090599810224710$

Josee, A., \& Etienne, S. J. (2007). Factors affecting the use of public support services by some owners: Evidence from a periphery region of Canada. Journal of Developmental Entrepreneurship, 12(2), 165-180. http://dx.doi.org/10.1142/S1084946707000629

Lewis, K., Massey, C., Ashby, M., Coetzer, A., \& Harris, C. (2007). Business assistance for SMEs: New Zealand owner-managers make their assessment. Journal of Small Business and Enterprise Development, 14(4), 551-566. http://dx.doi.org/10.1108/14626000710832695

Malaysia. (1971). Second Malaysia Plan 1971-1975. Kuala Lumpur.

Robson, J. A. P., \& Bennet, J. R. (2000). SME growth: The relationship with business advice and external collaboration. Small Business Economics, 15(3), 193-208. http://dx.doi.org/10.1023/A:1008129012953

Salleh, A. S., \& Ndubisi, N. O. (2006). An Evaluation of SME Development in Malaysia. International Review of Business Research Papers, 2(1), 1-14.

Westhead, P., \& Birley, S. (1995). Employment Growth in New Independent Owner-Managed Firms in Great Britain. International Small Business Journal, 13(3), 11-34. http://dx.doi.org/10.1177/0266242695133001 
Wiklund, J., \& Shepherd, D. (2005). Entrepreneurial Orientation and Small Business Performance: A Configurational Approach. Journal of Business and Venturing, 20. http://dx.doi.org/10.1016/j.jbusvent. 2004.01.001

Wren, C., \& Storey, J. D. (2002). Evaluating the effect of soft business support upon small firm performance. Oxford Economic Papers, 54(2), 334. http://dx.doi.org/10.1093/oep/54.2.334

\section{Copyrights}

Copyright for this article is retained by the author(s), with first publication rights granted to the journal.

This is an open-access article distributed under the terms and conditions of the Creative Commons Attribution license (http://creativecommons.org/licenses/by/3.0/). 